\title{
FACTORS INFLUENCING INTENTION TO USE E- GOVERNMENT SERVICES AMONG CITIZENS IN MALAYSIA
}

\section{OOH KIM LEAN}




\title{
FACTORS INFLUENCING INTENTION TO USE E-GOVERNMENT SERVICES AMONG CITIZENS IN MALAYSIA
}

By

\author{
Ooh Kim Lean
}

Research report in partial fulfillment of the requirements for the degree of Master of Business Administration

May 2008 


\section{ACKNOWLEDGEMENT}

I wish to express my heartfelt appreciation to my supervisor, Associate Professor Dr. Suhaiza Hanim Mohd Zailani and faithful thanks to my lecturer, Associate Professor Dr. T. Ramayah for their valuable guidance and encouragement throughout the research and thesis write up. I also wish to accord my appreciation to all respondents who had responded to this survey. My sincere thanks to all the lecturers in the MBA program as well.

Last but not least, I would also like to thank my family, for their kind understanding and encouragement during this period of my study, which fell during my pregnancy, delivery and maternity period.

Once again, Thank You Very Much. 


\section{TABLE OF CONTENTS}

ACKNOWLEDGEMENTS

$\frac{\text { Page }}{\text { ii }}$

$\begin{array}{ll}\text { TABLE OF CONTENTS } & \text { iii }\end{array}$

$\begin{array}{ll}\text { LIST OF TABLES } & \mathbf{x}\end{array}$

LIST OF FIGURES

ABSTRAK X xiii

ABSTRACT $\quad$ xiv

\section{Chapter 1: INTRODUCTION}

1.1 Introduction: Overview of e-Government 1

1.2 Background of e-Government 1

1.2.1 Government E-Payment Adoption Ranking 3

$\begin{array}{lll}1.3 & \text { Problem Statement } & 6\end{array}$

$\begin{array}{lll}1.4 & \text { Research Objectives } & 7\end{array}$

1.5 Research Questions $\quad 8$

$\begin{array}{ll}\text { 1.6 Definition of key terms } & 8\end{array}$

1.6.1 e-Government $\quad 8$

1.6.2 Perceived Ease of Use (PEOU) 9

$\begin{array}{lll}\text { 1.6.3 Perceived Usefulness } & 9\end{array}$

$\begin{array}{llr}\text { 1.6.4 Trust } & 9\end{array}$

1.6.5 Culture (Uncertainty Avoidance) 9

$\begin{array}{lll}\text { 1.6.6 Compatibility } & 9\end{array}$

1.6.7 Relative Advantage 9 
1.6.8 Image

1.6.9 Complexity

1.6.10 Perception of Authentication

1.6.11 Perception of Non-Repudiation

1.6.12 Perception of Confidentiality 10

1.6.13 Perception of Privacy Protection 10

1.6.14 Perception of Data Integrity

1.7 Significance of Study

1.8 Chapter Organization

\section{Chapter 2: LITERATURE REVIEW}

$2.1 \quad$ Introduction

2.2 Review of e-Government literatures 13

2.2.1 E-Government Process 13

2.2.2 Trust Dimensions and Antecedents of Trust 14

2.2.3 Diffusion of Innovation (DOI) 16

$\begin{array}{lll}2.2 .4 & \text { Institutional Trust } & 17\end{array}$

$\begin{array}{lll}2.2 .5 & \text { Interpersonal Trust } & 18\end{array}$

2.2.6 Theories and Models in Technology 19 Acceptance

2.2.6.1 Unified Theory of Acceptance 19 and Use of Technology

(UTAUT)

2.2.6.2 Theory of Reasoned Action

20 (TRA) 
2.2.6.3 Technology Acceptance Model

(TAM) and TAM2

2.2.6.4 Motivational Model (MM)

2.2.6.5 Theory of Planned Behavior (TPB)

2.2.6.6 Combined TAM-TPB (C-TAM-

2.2.6.7 Model of PC Utilization (MPCU)

2.2.6.8 Innovation Diffusion Theory (IDT)

2.4 The development of hypotheses 31

$\begin{array}{lll}\text { 2.4.1 Trust Factors } & 31\end{array}$

2.4.2 TAM Model 33

$\begin{array}{lll}\text { 2.4.3 DOI Model } & 33\end{array}$

2.4.4 DOI Model moderated by Uncertainty 35 Avoidance (Culture factor)

2.4.5 Intention to Use 36

2.5 Summary 36

\section{Chapter 3: METHODOLOGY}

$\begin{array}{lll}3.1 & \text { Introduction } & 37\end{array}$

3.2 Research Design 37

3.2.1 The purpose of the study 37 
3.2.3 Extent of the researcher interference with the study 37

3.2.4 Study Setting 38

3.2.5 Unit of Analysis 38

3.2.6 Time Horizon 38

3.3 Population, Sample Size and Sample Technique 38

$\begin{array}{lll}3.4 & \text { Data Collection } & 39\end{array}$

3.5 Questionnaire Design 40

3.6 Variable and Measurements $\quad 41$

3.6.1 Dependent Variable 42

3.6.1.1 Intention to Use 42

3.6.2 Independent Variables 42

3.6.2.1 Trust 42

3.6.2.2 Perceived Usefulness 42

3.6.2.3 Perceived Ease of Use 42

3.6.2.4 Compatibility 43

3.6.2.5 Relative Advantage 43

3.6.2.6 Image 43

3.6.2.7 Complexity 44

3.6.3 Moderating Variable 44

3.6.3.1 Uncertainty Avoidance 44

3.6.4 Antecedents of Trust 44

3.6.4.1 Perception of Authentication 44 
3.7 Data Analysis

3.7.5 Correlation Analysis, Multiple Regression and Hierarchical Regression

\section{Chapter 4: ANALYSIS AND RESULTS}

4.1 Introduction

4.2 Profile of Respondents

4.3.1.3 Perceived Usefulness \& 
$\begin{array}{lll}\text { 4.4 Descriptive Analysis } & 60\end{array}$

4.5 Revision of Theoretical Framework 61

4.6 Revision of Hypotheses 64

$\begin{array}{lll}4.7 & \text { Correlations } & 65\end{array}$

4.8 Hypotheses Testing $\quad 67$

$\begin{array}{lll}\text { 4.8.1 Trust and its antecedents } & 67\end{array}$

4.8.2 Trust toward Intention to Use e-Government 69

4.8.3 Perceived Usefulness and Intention to Use 70 e-Government

4.8.4 Diffusion of Innovation (DOI) and Intention 71 to Use e-Government

4.8.4.1 Testing moderating effect $\quad 72$

4.9 Hypotheses Analysis Result $\quad 74$

4.10 Summary of the Result 76

\section{Chapter 5: DISCUSSION AND CONCLUSION}

$\begin{array}{lll}5.1 & \text { Introduction } & 77\end{array}$

$\begin{array}{ll}5.2 & \text { Recapitulation of the Study }\end{array}$

$\begin{array}{lll}5.3 & \text { Discussion of major finding } & 78\end{array}$

5.3.1 Antecedents of Trust 78

$\begin{array}{lll}\text { 5.3.2 Trust } & 80\end{array}$ 
5.3.4 Diffusion of Innovation (Complexity, Relative Advantage and Image)

5.3.5 Uncertainty Avoidance (Moderating Effect)

\section{REFERENCES}




\section{LIST OF TABLES}

$\underline{\text { Page }}$

Table 1.1 Ranks and scores in the Government E-Payment Adoption Ranking 4 (GEAR)

Table 1.2 The 31 indicators in the Government E-Payments Adoption

Ranking

Table 3.1 Distribution of Questionnaire Items

Table 4.1 Profile of the Respondents

Table 4.2 Respondents’ Technology usage and e-government website usage

Table 4.3 Factors Loading for Antecedents of Trust

Table 4.4 Factor Loading for Trust

Table 4.5 Factor Loading for Perceived Usefulness (PU) toward intention to 56 use e- Government Services

Table 4.6 Factors Loading for Diffusion of Innovation Model (DOI) 57

Table $4.7 \quad$ Factor Loading for Uncertainty Avoidance (Culture) 58

Table 4.8 Factor Loading for Intention to use 59

$\begin{array}{lll}\text { Table } 4.9 & \text { Reliability Analysis } & 59\end{array}$

Table 4.10 Descriptive Statistics Descriptive Statistics 60

Table 4.11 Factors’ Label 62

Table 4.12 Inter-correlations of the Major Variables 66

$\begin{array}{lll}\text { Table } 4.13 & \text { Hypotheses Testing Arrangement } & 67\end{array}$

Table 4.14 Regression Results on antecedents of trust to trust 68

Table 4.15 Regression Results on Trust toward Intention to Use $\quad 70$ 
Table 4.16 Regression Results on Perceived Usefulness toward Intention to 71 Use

Table 4.17 Hierarchical Regression Results Hierarchical Regression Results 73

Table 4.18 Summary of Hypotheses Analysis Results 75 


\section{LIST OF FIGURES}

Page

Figure 2.1 Unified Theory of Acceptance and Use of Technology (UTAUT 20 Model)

Figure 2.2 Proposed TAM2 - Extension of the Technology Acceptance Model 23

$\begin{array}{lll}\text { Figure 2.3 The Theoretical Framework } & 30\end{array}$

Figure 4.1 The Revised Theoretical Framework 63 


\begin{abstract}
ABSTRAK
Kajian ini adalah kajian explorasi mengenai kerajaan elektronik di Malaysia. Dengan kewujudan liberasi dan globalisasi, Internet telah menjadi medium transaksi dalam semua aspek kehidupan manusia. Kajian ini adalah kajian tentang faktor-faktor yang mempengaruhi niat untuk mengguna kerajaan elektronik kalangan penduduk Malaysia. Model yang digunakan dalam kajian ini merupakan integrasi daripada Technology Acceptance Model (TAM), Diffusion of Innovation (DOI) dimoderasikan oleh faktor budaya dan Model Kepercayaan dengan 5 dimensi. Kertas soal selidik yang berstruktur telah digunakan untuk mengumpul data daripada 195 individu tetapi hanya 150 soal selidik yang lengkap diambil untuk tujuan analisis. Daripada analisis, didapati bahawa kepercayaan, tanggapan kebergunaan, kebaikan relatif dan imej masing-masing mempunyai hubungan positif yang signifikan terhadap niat mengguna kerajaan elektronik manakala faktor kompleks mempunyai hubungan negatif terhadap niat untuk mengguna kerajaan elektronik. Manakala kekuatan faktor privacy dan kekuatan faktor non-repudiation juga mempunyai kesan positif terhadap kepercayaan individu untuk menggunakan kerajaan elektronik. Namun begitu, faktor pengantaraan “uncertainty avoidance” tidak memberi sebarang kesan terhadap hubungan antara faktor Inovasi (seperti kompleks, kebaikan relatif dan imej) dengan niat untuk mengguna kerajaan elektronik. Akhirnya, didapati model DOI memberi kuasa penjelasan yang lebih baik dibandingkan dengan Model TAM dan Model Kepercayaan.
\end{abstract}




\begin{abstract}
This study is an exploratory study on the e-government in Malaysia. With the liberalization and globalization, Internet has been used as a medium of transaction in almost all aspects of human living. The study is investigating the factors that influencing the intention to use egovernment service among Malaysians. This study integrates constructs from the models of Technology Acceptance Model (TAM), Diffusion of Innovation (DOI) which been moderated by culture factor and Trust model with five dimensions. The study was conducted by surveying a broad diversity of citizens in Malaysia community. Structured questionnaire was used to collect data from 195 respondents but only 150 of the respondents with complete answers participating in the study. The result of the analysis showed that trust, perceived usefulness, perceived relative advantage and perceived image respectively has a direct positive significant relationship towards intention to use e-government service and perceived complexity has a significant negative relationship towards intention to use e-government service. While perceived strength of online privacy and perceived strength of non-repudiation have a positive impact on a citizen's trust to use e-government service. However, the uncertainty avoidance (moderating factor) used in the study has no significant effect on the relationship between the innovation factors (complexity, relative advantage and image) and intention to use e-government service. Finally in comparing the explanatory power of the entire intention based model (TAM, DOI and Trust) with the studied model, it has been found that the DOI model has a better explanatory power.
\end{abstract}




\section{Chapter 1}

\section{INTRODUCTION}

\subsection{Introduction: Overview of e-Government}

As one of the strategies to achieve Vision 2020, Multimedia Super Corridor (MSC) has been introduced to accelerate Malaysia’s entry into Information Age. The services provided through the website are the Government's proactive way to help enhance the public delivery system. Electronic Government (e-Government) was initiated in Malaysia on 24 February 2004. The Vision of e-Government is to transform administrative process and service delivery through the use of IT and multimedia. E-Government is an initiative aimed at reinventing how the Government works and to improve the quality of interactions with citizens and businesses through improved connectivity, better access, furnishes high quality services and better processes and systems.

This introductory chapter starts with providing background of the study. The chapter then explains the problem of the study, research objectives and research questions. Then, the chapter portrays the significance of the study and its expected contributions. This chapter ends with definition of key terms of the study and organization of the remaining chapters of the thesis.

\subsection{Background of e-Government}

The Malaysian government has launched a website to collate all the services provided under one roof or portal rather than having separate website for respective services provided (http://www.msc.com.my/msc/flagships.asp). Under the e-government flagship, 7 pilot projects of E-Government Flagship Application are identified as Generic Office Environment (GOE), Electronic Procurement (EP), Human Resource Management Information System (HRMIS), 
Project Monitoring System (PMS), Electronic Services Delivery (E-Services), Electronic Labor

Exchange (ELX), and E-Syariah (MDC,2004). The myGovernment Portal (www.gov.my) could be described as one-stop source of Malaysian government information and services for the citizens. The digital government plays an important role to provide public service a fast, easy and with integrity information at a click. For instance, E-Syariah portal plans to allow teleconferencing and mediation via the Internet to upgrading the service level and will be able to bring down the current number of backlog cases at the Syariah court (The Star, 19 Apr 2007). Through the portal, public will be able to file suit or affidavits online, get mention date for a hearing and follow up on the status of their cases without having to step foot into the hallowed halls. Under the application of Electronic Labor Exchange (ELX) designed exclusively to Malaysians only, it provides free online services to help match potential employers with jobseekers. The website lists down 395 online services of ministries, departments and agencies and 3,300 Government forms can be downloaded for free.

The Malaysian Administrative Modernization and Management Planning Unit (MAMPU) is promoting the use of e-Government among the public. Among the online services provided under the website include zakat, loan and quit rent payments, application to update mailing address with the Employees Provident Fund, application to the Museum Department to extend the archaeological search license and to apply for foreign workers with the Immigration Department. There are also "Quick Links" direct to the Government machinery, directory, tenders, job vacancies, public complaints and even to get information on the weather. Information pertaining to taxation, health, education, legal and family such as pregnancy, adoption and even marriage issues, are just a click of the mouse away (The Star, 27 March 2007). 
From a technological perspective, e-Government is the use of information and telecommunication (ICT) and multimedia technologies to improve the access to and delivery of government's services to benefit all citizens individually, businesses or organizations. EGovernment is the application of ICT and multimedia technologies to transform the efficiency, effectiveness, transparency and accountability of informational and transactional exchanges between the government and the citizens. Generally, e-Government portal will be the one-stop gateway to administrative and commercial services.

With the e-Government portal, the citizens would undoubtedly benefit by able to access the various government's services at any time and any place conveniently. However, relatively little has been known about the adoption of e-Government among public citizens so far. According to the report by Road Transport Department, people still spend time to line up at the counter to pay their summonses. There were 100, 847 enquiries from the public regarding to their summonses between Jan till Apr 2007, but nobody paid online (The Star, 31 Jul 2007). If many citizens are not keen to adopting and using e-Government services, those large investments from governments could be simply wasted. Motivated by this important issue, this research intends to explore the key factors influencing the intention to use e-Government among the public citizens.

\subsubsection{Government E-Payment Adoption Ranking}

The Economist Intelligence Unit conducted the Government E-Payment Adoption Ranking (GEAR), measures the extent to which 43 countries provide key government payment services on electronic platforms (Ranking result shown in Table 1.1). Economist Intelligence Unit analysts and contributors conducted online research to test 16 important transactions, including tax payments and refunds, automotive costs, social-welfare benefits, registration of businesses and government procurement. The unit gathered data on these countries' payments 
infrastructure, and their educational, economic and political context. The 31 indicators in this study were built into a dynamic scoring model (Indicators shown in Table 1.2)

Based on the research, Canada is the world's leading nation for government e-payments (with the highest score of 92.4 out of 100), edging the UK in second (92.1), Germany and the United States in third (90.1). The ranking followed by Sweden (89.6), Australia (88.0) and South Korea (86.8) round out the top seven. These countries' government combine welldeveloped information and communications infrastructures, technologically and financially sophisticated populations, and governments committed to electronic payments and to integrating the economy.

In Asian countries, Hong Kong was ranked in 9th (86.4), Singapore in 10th (85.6) and Taiwan in 11th (84.5). The governments of these countries have encouraged online services and electronic payments in recent years as part of their successful economic-development strategies. The report revealed that Malaysia was ranked in 24th (49.1), showed that Malaysians are still low in utilizing e-services provided by government. Motivated by this important issue, this research intends to explore the key factors influencing the intention to use e-Government among the citizens in Malaysia.

Table 1.1 Ranks and scores in the Government E-Payment Adoption Ranking (GEAR)

\begin{tabular}{llrllr}
\hline Rank & Countries 1-22 & Score & Rank & Countries 23-43 & Score \\
\hline 1 & Canada & 92.4 & 23 & Philippines & 51.2 \\
\hline 2 & United Kingdom & 92.1 & $\mathbf{2 4}$ & Malaysia & $\mathbf{4 9 . 1}$ \\
\hline 3 tie & Germany & 90.1 & 25 & Mexico & 48.2 \\
\hline 3 tie & United States & 90.1 & 26 & Russia & 45.5 \\
\hline 5 & Sweden & 89.6 & 27 & Poland & 45.3 \\
\hline 6 & Australia & 88.0 & 28 & Argentina & 44.7 \\
\hline 7 & Korea, Rep. of & 86.8 & 29 & Thailand & 42.0 \\
\hline 8 & France & 86.6 & 30 & Kazakhstan & 40.8 \\
\hline 9 & Hong Kong & 86.3 & 31 & United Arab Emirates & 39.1 \\
\hline 10 & Singapore & 85.6 & 32 & Pakistan & 38.4 \\
\hline 11 & Taiwan & 84.5 & 33 & India & 34.6 \\
\hline 12 & Netherlands & 81.6 & 34 & Colombia & 31.2 \\
\hline 13 & Spain & 76.4 & 35 & Morocco & 28.3 \\
\hline 14 & Ireland & 75.0 & 36 & Costa Rica & 28.2 \\
\hline 15 & Italy & 74.2 & 37 & Iran & 23.8 \\
\hline 16 & Hungary & 73.4 & 38 & Saudi Arabia & 20.9 \\
\hline
\end{tabular}




\begin{tabular}{llllll}
\hline 17 & Japan & 66.4 & 39 & Egypt & 19.0 \\
\hline 18 & Turkey & 61.6 & 40 & Venezuela & 18.7 \\
\hline 19 & China & 61.1 & 41 & Ukraine & 14.6 \\
\hline 20 & Czech Republic & 58.8 & 42 & Nigeria & 13.6 \\
\hline 21 & South Africa & 53.8 & 43 & Indonesia & 12.8 \\
\hline 22 & Brazil & 52.8 & & & \\
\hline
\end{tabular}

Source: The Economist Intelligence United Limited, Oct 2007

Table 1.2 The 31 indicators in the Government E-Payments Adoption Ranking

\begin{tabular}{|c|c|}
\hline Indicator name & Indicator type \\
\hline \multicolumn{2}{|l|}{ Consumer-to-government (C2G) } \\
\hline 1. Income tax payments & Score \\
\hline 2. Social security contributions & Score \\
\hline 3. Obtaining and paying for a new or replacement ID card or driver's license & Score \\
\hline 4. Automotive costs: Toll roads, bridges, zones, fines, tickets etc & Score \\
\hline \multicolumn{2}{|l|}{ Government-to-consumer (G2C) } \\
\hline 1. Income tax refunds & Score \\
\hline 2. Social security benefits & Score \\
\hline 3. Unemployment, workers' comp and welfare benefits & Score \\
\hline 4. Government health benefits & Score \\
\hline \multicolumn{2}{|l|}{ Business-to-government (B2G) } \\
\hline 1. Income tax payments & Score \\
\hline 2. Sales/VAT tax payments & Score \\
\hline 3. Social security and other contributions & Score \\
\hline 4. Company registration and payment of fees & Score \\
\hline \multicolumn{2}{|l|}{ Government-to-business (G2B) } \\
\hline 1. Income tax refunds & Score \\
\hline 2. Sales/VAT tax refunds & Score \\
\hline 3. Payments for goods and services & Score \\
\hline 4. Disbursements of loans (such as SBA in the US) & Score \\
\hline \multicolumn{2}{|l|}{ Infrastructure } \\
\hline 1. Number of ATMs per 10,000 people & Statistic \\
\hline 2. Number of POS terminals per 10,000 people & Statistic \\
\hline 3. Diffusion of broadband & Score \\
\hline 4. Diffusion of narrowband/dial-up & Score \\
\hline 5. Public-access terminals per capita & Score \\
\hline 6. Mobile phone usage per capita & Score \\
\hline 7. Level of development of stored value cards/phones & Score \\
\hline 8. Level of development of $3 \mathrm{G}$ and other technologies & Score \\
\hline \multicolumn{2}{|l|}{ Educational, economic and political context } \\
\hline 1. Literacy levels & Statistic \\
\hline 2. Educational levels & Statistic \\
\hline 3. Internet/technology savviness & Score \\
\hline 4. Percentage of population using banks/other financial institutions & Score \\
\hline 5. Percentage of businesses using banks/other financial institutions & Score \\
\hline 6. Government commitment to electronic payments & Score \\
\hline 7. Government commitment to integrating the informal economy & Score \\
\hline
\end{tabular}

Source: The Economist Intelligence United Limited, Oct 2007 


\subsection{Problem Statement}

The mission to implement e-government by most countries has increase tremendously due to its potential and positive impacts. However, the complexity of the implementation of egovernment is also creating challenges to the government in influencing citizens' intention to use the e-government services. The most significant characteristic of any successful egovernment application is its quality and accessibility. Other issues such as integration of legacy systems, installation of appropriate security and privacy mechanism, authentication and confidentiality, technical issue, infrastructure, accessibility, maintainability, social issues, usability and others need to be studied to increase citizens' actual participation in the usage of e-government initiatives.

Despite the myriad of services which available online, most of the people still prefer to conduct their official matters the old-fashioned way. An example is the online payment facility for police and Road Transport Department (RTD) summonses, which was painstakingly put into place when the concept of electronic government was first launched. Despite the facility being around for slightly less than a decade, only 17 people chose the option of paying their traffic summonses through government websites in year 2006, amounting to a paltry RM3,015. Most people are just using these websites to check their summonses instead of fully utilize the online facility given (The Star, 31 Jul 2007). The reluctance of the general public to trust, to perceived usefulness and accept the innovativeness of e-services provided by government to conduct their official matters is an "issue that needs to be addressed". For instance, there are citizens who prefer to continue to submit their annual income tax by filling up the hard copy form instead of using e-filing system, which was introduced to public and readily for their usage. The relatively low intention to use e-government services may be due to instability of the e-services system such as server down (difficult to access to the system), privacy, 
confidentiality, non-repudiation, data integrity, authentication, complexity, uncertainty avoidance by the society and incompatibility to the existing living style.

Based on the Government E-Payment Adoption Ranking (GEAR), Malaysia was ranked in $24^{\text {th }}$ out of 43 countries in the world. This report indicated that more study need to be done to analyze factors influencing the intention to use e-government services among citizens in Malaysia. In addition, the government authorities also have to study their strategies in encouraging more citizens to use e-government services in future.

\subsection{Research Objective}

To keep pace with the fast moving world of automation and digitization, Malaysia government need to provide a quality e-government services to enhance confidence among citizens to use the online services provided by government in more effective and efficient way. As the challenges arising from implementation of e-government are extensive with potential problem, which consequently decrease the participation among citizens, the core research of this paper is to gauge the factors influencing Malaysia citizens’ intention to use e-government services.

This research would specifically help

1) To investigate the antecedents of Trust in the context of e-government services in Malaysia

2) To determine whether trust has direct relationship influencing the intention to use egovernment services.

3) To evaluate which intention based model (i) Technology Acceptance Model (TAM), (ii) Diffusion of Innovation (DOI) can better explain in understanding factors influencing intention to use e-government services.

4) To determine whether the culture (uncertainty avoidance) as a moderator has any effect between factors in DOI model and intention to use e-government services. 


\subsection{Research Questions}

Based on the statement of the problem, this study attempts to answer the following research questions:

1) What are the antecedents that influence the level of trust toward e-government in Malaysia?

2) Is trust an important factor in the intention to use e-government Services in Malaysia?

3) Among the intention-based model (i) Technology Acceptance Model (TAM), (ii) Diffusion of Innovation (DOI), which model better explain in understanding intention to use e-government Services.

4) To determine whether culture factor - uncertainty avoidance has effect on the relationship between innovation factors and intention to use e-government services

\subsection{Definition of key terms}

\subsection{1. e-Government}

The application of the Internet in the operation of the government has been termed as ' $\mathrm{e}$ government' (Cohen and Eimicke, 2002; Harris, 2002; Jorgensen and Cable, 2002). Egovernment can be defined as "the complete optimization of service delivery, constituency participation and governance by transforming internal and external relationships through technology, the Internet and new media” (Gartner et al., 2000). It presents a way for governments across the world to provide citizens, business and other government with convenient access to government services and opportunities of collaboration via Internet and wireless communication technology (Siau K. and Long Y., 2005). 


\subsubsection{Perceived Ease of Use (PEOU)}

The degree that users believe that using the system is easy or expects the target system to be free of effort, and that it directly increases perceived usefulness (Davis, 1989).

\subsubsection{Perceived Usefulness (PU)}

The degree that users believe a particular system facilitates their activity. It is subjective probability that using a specific application system will increase his or her job performance (Davis, 1989).

\subsubsection{Trust}

Trust refers to the extent to which users believe the web site is legal, ethical and credible and is able to protect their privacy (Wan, 2000). Trust is an assessment by the online consumer in regards to the trustworthiness of the electronic vendor (Felix \& Paul, 2004).

\subsubsection{Culture (Uncertainty Avoidance)}

The degree to which societies can tolerate uncertainty and ambiguity differs among cultures (Hofstede, 1980).

\subsubsection{Compatibility}

Rogers (1995) defines compatibility as the degree to which an innovation is seen to be compatible with values, experiences, beliefs, and needs of adopters.

\subsubsection{Relative Advantage}

Relative advantage is defined as the degree to which an innovation is seen as being superior to its predecessor (Rogers, 1995). 


\subsubsection{Image}

Image refers to one’s perceptions of innovation as a status of symbol (Rogers, 1995).

\subsubsection{Complexity}

Complexity is the degree to which an innovation is seen by the potential adopter as being relatively difficult to use and understand (Rogers, 1995)

\subsubsection{Perception of Autenticatin}

Authentication allows a certain operation to be carried out only after identification, or if there are guarantees of the identity of the party one is dealing with (Bomil \& Ingoo, 2003).

\subsubsection{Perception of Non-Repudiation}

Non-repudiation refers to procedures that prevent an individual or organization from denying that they had carried out a certain operation. According to Bomil \& Ingoo (2003), Nonrepudiation means that neither of the trading parties should be able to deny having participated in a transaction after the fact.

\subsubsection{Perception of Confidentiality}

Confidentiality involves the data being seen by authorized individuals. According to Pauline (1998), confidentiality has been defined as the act of warranting that data are only revealed to parties who have a legitimate need to know it or have access to it.

\subsubsection{Perception of Privacy Protection}

When online services are concerned, privacy affects aspects such as the obtaining, distribution or the non-authorized use of personal information (Wang, Y.S., Wang, Y.M., Lin, H.H.,\& Tang 
T.I., 2003). According to Bomil \& Ingoo (2003), privacy protection ensures that personal information about customers collected from their electronic transactions is protecting from disclosure without permission.

\subsubsection{Perception of Data Integrity}

The integrity of an information system refers to the impossibility of the transmitted or stored data being modified by third parties without permission. According to Bomil \& Ingoo (2003), data integrity means that data in transmission are not created, intercepted, modified, or deleted illegitimately.

\subsection{Significance of Study}

This research is study the intention to use e-Government among citizens in Malaysia. This research can help the policy maker to know the information on factors that influence and affect citizens' intention to use e-Government services in Malaysia. Hence, it would value add in establishing better understanding and more practical security and control policies that would strengthen the government portal or websites that citizen concern the most. This would also help the government to identify which critical area that needs to be enhanced.

Ultimately, the most critical outcome that we would expect out of this study is to increase the confidence of citizens to use e-Government in future.

\subsection{Chapter Organization}

This thesis comprises of five chapters. We started with an overall view of the study by introducing the background scenario, which lead to this study. Chapter 2 covers the literature review of this project by discussing the factors concern in different models by previous researchers, the development of theoretical framework and hypothesis generation. Chapter 3 
continues with the research methodology such as sampling design, data collection, questionnaire design and statistical analysis used. Subsequently, Chapter 4 embodies the result of the data analysis. Finally, Chapter 5 presents the research finding discussion, the implication of the study, limitation of the study and suggestion for the future research are also provided. 


\section{Chapter 2}

\section{LITERATURE REVIEW}

\subsection{Introduction}

This chapter seeks to reviews the relevant literature that forms the base for this study. The review compares and contrasts the finding from previous researchers. The theoretical framework and hypothesis intricate the different factors exist in influencing the intention towards using e-government services among citizens in Malaysia.

\subsection{Review of e-Government Literatures}

\subsubsection{E-Government processes}

In contrast to traditional government processes, e-Government is characterized by (1) extensive use of communication technology (2) the impersonal nature of the online environment (3) the ease of information can be collected (data-mining), processed and used by multiple parties (Warkentin, Gefen, Pavlou \& Rose, 2002). However, e-Government has the implicit uncertainty of using an open technological infrastructure for transaction via the newness of the communication medium - interact with a government website. This would indirectly increase the spatial and temporal separation between citizens and government; more uncertainty and concern about the reliability of the underlying Internet and related government infrastructure interfaces. As overall these unique differences increase uncertainty and reduce perception of citizen control, imposing a barrier to e-Government adoption.

A number of research papers in e-Government were published in recent years to help practitioners to improve government service quality, responsiveness, convenience and accessibility to both citizens in urban and rural area. Their effort can be categorized into few issues: (i) The concept, theories, history, structure, initiatives, policy, key principles, impact, challenges, and development success factors of e-Government; (ii) The technology application, 
knowledge spillover, innovative efforts and approach to facilitate e-Government implementation and evaluation; (iii) Management support or implementation strategies such as framework for managing the lifecycle of transactional e-Government services to facilitating the e-Government services. To provide more intuitive and maintainable lifecycle for electronic tax submission (one of the e-government service to citizens), government must overcome shortcoming happen during the lifecycle such as implicit knowledge, user interaction, code reusability, communication with back-end system, business reengineering required to upgrade to workflow flexibility and resolve security issue (Vassilakis, Laskaridis, Lepouras, Rouvas \& Georgiadis 2003) (iv) the assessment, measurement of e-Government services provided to public sector and its effects on economic, social benefits of the implementation; (v) key factors affecting acceptance, expectation and usage intention of e-Government services. The study on "Utilization of e-government services" discussed that compatibility; trustworthiness and perceived ease of use have direct positive relationship towards citizens' intention to use the eGovernment services (Carter \& Belanger, 2005).

\subsubsection{Trust dimensions and Antecedents of Trust}

Generally, across discipline there is agreement that trust only exists in an uncertain and risky environment. Mayer et al. (1995) as cited in Sonja and Ewald (2003) explained that trust would not be needed if actions could be undertaken with complete certainty and no risk. One important reason for the importance of trust in e-government service is the fact that in a virtual environment the degree of uncertainty of online transactions is higher than in traditional setting.

In addition, Rousseau, Sitkin, Burt, \& Comerer (1998) claimed that trust is a psychological state comprising the intention to accept vulnerability based upon positive expectation of the intention or behavior of another. In identifying risk and vulnerability as the central situational feature of trust, we can see the important of this holds in the web services 
setting. This vulnerability is magnified in the online situation due to the nature of the Internet as compared to the traditional setting.

Perception of trustworthiness could impact citizen's intention to use e-government services. Trustworthiness is also defined as the perception of confidence in the electronic marketer’s reliability and integrity (Belanger, Hiller \& Smith, 2002). According to Belanger et al. (2002), users must have confident in both the government and the enabling technologies. A survey reported by GAO (2001), Americans believe that e-government has the potential to improve the way government operates, but they have concerns about sharing personal information with the government over the internet, fearing that the data will be misused and their privacy diminished. Privacy and security are reoccurring issues in e-commerce and egovernment research (Belanger and Hiller, 2005; Chadwick, 2001; Fernandez, 2001; GAO, 2001; Hoffman et al., 1999; Miyazaki and Belanger et al., 2002).

Authentication in an e-government context is typically an act of establishing or confirming someone or something as authentic, concerning any process through which one proves and verifies certain related information. Identification is an act of establishing or confirming the identity of a person. Poor coordination in the development and application of relevant services as well as a too low level of trust in e-government are the main barriers in the e-government adoption by citizens (eGovernment Unit, DG Information Society, European Commission, 2006). For example, assess transactions for authentication requirements in a realistic way to avoid probability of someone fraudulently pay fines or taxes on someone else's behalf.

On the other hand, digital signature was selected as a crucial element for providing secure networked services. The goal of a digital certificate is to assure the authenticity and validity of the binding of public keys and principal names. A digital signature links a person's exclusive identity to an electronic document or transaction to accomplish what a written 
signature accomplishes. Hence, a digital signature provides signer and document authentication. Signer authentication is the ability to identify the person who digitally signed the document. This also provides non-repudiation, which means a signer cannot deny they signed a document or transaction (Carrigan, R., Milton, R., \& Morrow, D., 2005) Furthermore, the digital certificates have the ability to encrypt information so the information cannot be understood by any other than the intended party.

In the context of trustworthiness, there are two main items that will be related to behavior intention. The items are trust of Internet (TOI) and trust of government (TOG). The decision to engage in e-government transaction requires users' trust in the state government agency providing the service and users' trust in the technology through which electronic transactions are executed via the Internet (Lee \& Turban, 2001). Higher degree of trustworthiness will lead to higher intention to use e-government services.

\subsubsection{Diffusion of Innovation (DOI)}

The individual's decision on whether to use the technology is based on perception of the technology such as compatibility, relative advantage, image and complexity (Gilbert, D. \& Balestrini, P., 2004). Previous study has identified the link between perceived usefulness (relative advantage in innovation diffusion theory) and compatibility (Rogers, 2003). The argument revealed that if the individual perceives an innovation to be inconsistent with his current practice, he would tend to be more uncertain about the expected benefits of the innovation.

According to Rogers (2003), the social prestige that the innovation presents to its adopter may be the sole benefit that the adopter receives. From the previous research done by Phang, C.W., Li, Y., Sutanto, J., and Kankanhalli, A. (2005), in the context of Central 
Provident Fund (CPF) e-Withdrawal service adoption by senior citizens, those senior citizens that adopted the service may impress others that even though they are old in age, they are still able to learn and use up to date technologies which in line with the changes in society. This may enhance their social status and enable them to serve as role models for other senior citizens who have not adopted this e-government service.

\subsubsection{Institutional Trust}

According to Warkentin, Gefen, Pavlou \& Rose (2002), institutional trust deals with third party guarantors that provide (1) certification about the trustworthiness and expected behavior of a person (2) escrows that guarantee expected outcome of the interaction. For instance, citizen trust of the government agency managing the online tax process should also be built by independent third party certification that it will behave in a certain manner by trustworthy people. In the e-service which related to monetary transaction, a third party guarantor could verify that the money is not made available to the government until a third party verifies that the transaction is correct.

Basically, it is at institutional level that the individual's perception of regulatory, legal and technical environment comes to fruition. If individual do not believe the Internet offers adequate regulatory, legal or technical protection, they are unlikely to hold a high level of institutional trust in the Internet as shopping medium (McKnight \& Chervany, 2001-2002). Zucker (1986) as cited in Sojan and Ewald (2003) claimed that institutionally based trust production, in which formal mechanisms are used to provide trust that does not rest on personal characteristics or on past history of exchange, helps to reduce both system-dependent and transaction specific uncertainty.

There are two dimensions of institution-based trust, which defined as structural assurance and situational normality. Structural assurance means one believes that structures like 
guarantees, regulations, promises, legal resource, other procedures are in place to promote success. Situational normality means one believes that the environment is in proper order and success is likely because the situation is normal or favorable (McKnight et al., 2002).

\subsubsection{Interpersonal Trust}

From Interpersonal trust perspective, there are few attributes has used to develop trust in another party, namely competence, predictability, benevolence, and integrity. Dealing with competence, consumers assess whether vendors have the appropriate abilities, skills and expertise to satisfy their needs. Predictability takes into account the vendor's perceived reputation for providing a consistent service. Integrity is the belief that the Internet vendor will act in an honest fashion and adhere to a set of principles or standards. When looking at benevolence, the consumer makes a judgment on whether the vendor is focused on making a fast profit or as the customer's best interests in mind. According to Felix \& Paul (2004), each of these attributes of interpersonal trust is measured by the consumer's impression of the Internet vendor, drawn from previous experience or gathered from outside sources of information.

McKnight and Chervany (2002) claimed that trusting beliefs means the confident truster perception that the trustee - in this context, specific web-based vendor- has attributes that are beneficial to the truster. On the other hand, Bomil and Ingoo (2003) found that trust belief also encompasses three characteristics, namely, competence (ability of the trustee to do what the truster needs), benevolence (trustee caring and motivation to act in the truster's interests), and integrity (trustee honesty and promise keeping) which similar to the attributes of interpersonal trust. 


\subsubsection{Theories and Models in Technology Acceptance}

\subsubsection{Unified Theory of Acceptance and Use of Technology (UTAUT)}

Relatively, various theoretical models have been designed and planned to investigate technology acceptance in the information technology literature. The research model to be developed and tested in this study draws on findings from relevant prior research primarily based on the Unified Theory of Acceptance and Use of Technology (UTAUT) model (Venkatesh et al., 2003). UTAUT model was built upon and extends beyond the well established Technology Acceptance Model (TAM) (Davis, 1989; Davis et al., 1989). Vankatesh, et al. (2003) have proposed a more comprehensive model, Unified Theory of Acceptance and Use of Technology (UTAUT) model which unified the various model of information technology acceptance that integrated the elements of eight prominent models, namely Theory of Reasoned Action (TRA) (Fishbein \& Ajzen 1975), Technology Acceptance Model (TAM) (Davis, 1989; Davis et al., 1989), Motivational Model (MM) (Davis et al., 1992, as cited in Venkatesh et al., 2003), Theory of Planned Behaviour (TPB) (Ajzen, 1991), Combined TAM-TPB (Taylor \& Todd, 1995), Model of Personnel Computer (PC) Utilization (MPCU) (Thompson, Higgins, \& Howell, 1991), Innovation Diffusion Theory (IDT) (Roger 1995), and Social Cognitive Theory (SCT) (Bandura, 1986). Comparing UTAUT and previous models, UTAUT was able to explain 70\% of technology acceptance behaviour, a considerable improvement on previous models, which routinely explain over $40 \%$ of acceptance (Venkatesh et al., 2003). Therefore, UTAUT is considered an enhanced model with parsimonious and robust characteristics that could better explain the factors influencing individual's intention and usage. In detail, UTAUT contains four core determinants of intention and usage namely performance expectancy, effort expectancy, social influence and facilitating conditions (Venkatesh et al., 2003). The variable gender, age, experience and voluntariness of use moderate the key relationships in the model. 


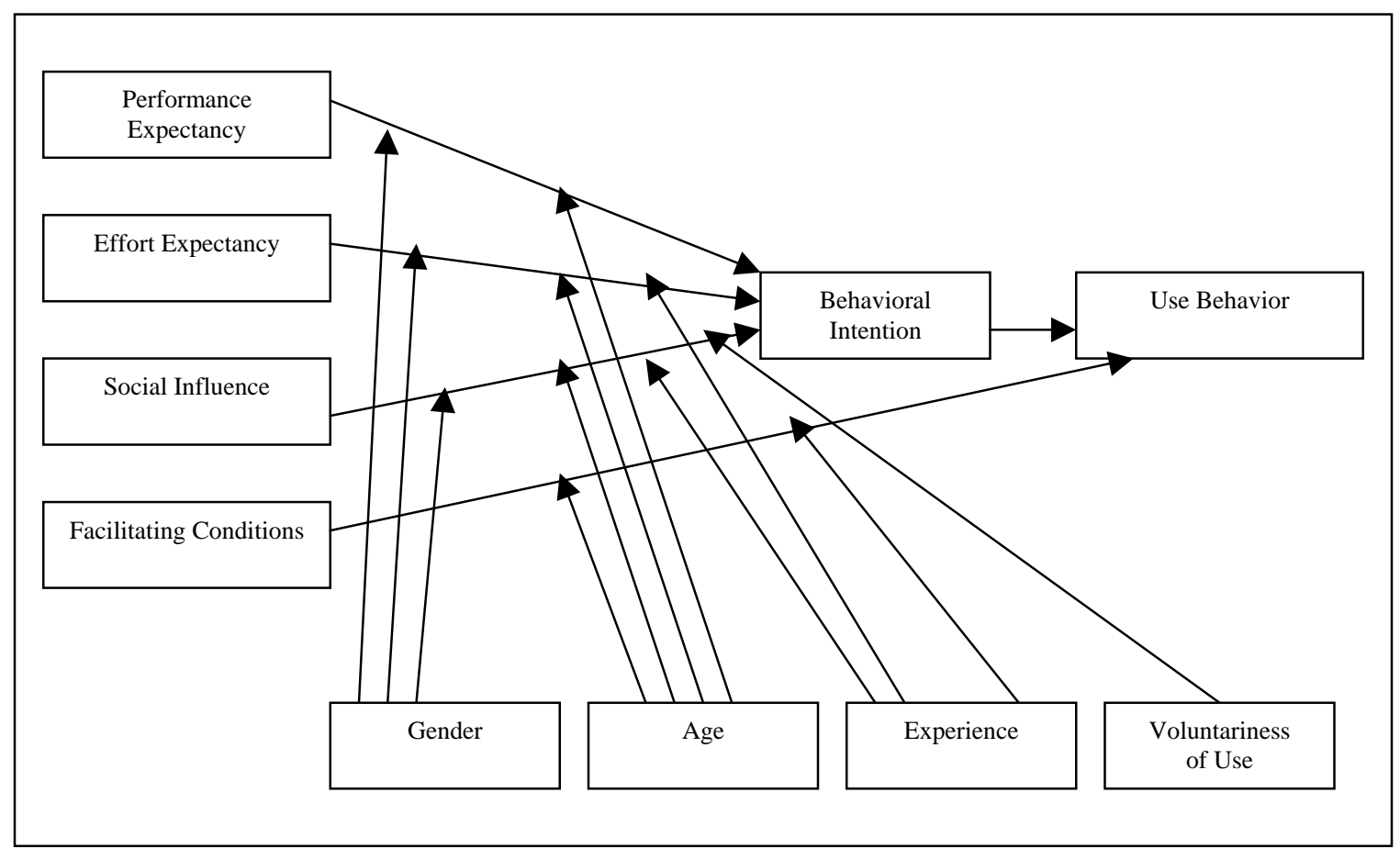

Figure 2.1 Unified Theory of Acceptance and Use of Technology (UTAUT) Model Source: Venkatesh et al., 2003

\subsubsection{Theory of Reasoned Action (TRA)}

Theory of Reasoned Action (TRA) (Fisbein, Ajzen, 1975) is one the first theories to explain computer usage and acceptance behavior. According to the TRA, intention to perform behavior (BI) are determined by the person's attitude (A) and subjective norm (SN) regarding the behavior in question. Attitude (A) is determined by his or her salient beliefs about the results of performing the behavior multiplied by the evaluation of those results. Salient beliefs can be obtained by taking the beliefs most frequently elicited from a representative sample of the population. SN is determined by a multiplicative function of his or her normative beliefs, i.e. perceived expectations of specific referent individuals or group, and his or her motivation to comply with these expectation or beliefs. 


\subsubsection{Technology Acceptance Model (TAM), and TAM2}

Technology Acceptance Model (TAM) (Davis, Bagozzi \& Warshaw, 1989) adopts TRA’s causal links to explain individual's IT acceptance behavior. It suggests that perceived usefulness (PU) and perceived ease of use (PEOU) of IT are major determinants of its usage. PU was defined as the degree of which a person believes that using a particular system would enhance his or her job performance and PEOU was defined as the degree, which a person believes that using a particular system would be free of effort. Both PU and PEOU are jointly influence citizens’ intention. Davis et al (1989) assert, “A key purpose of TAM is to provide a basis for tracing the impact of external factors on internal beliefs, attitudes and intentions”. Behavior Intention (BI) is a measure of the strength of one's intention to perform a specified behavior. According to intention-based theories, user adoption and usage behavior are determined by the intention to use IT. It is a kind of "self prediction" or "behavioral expectation”, indicated as one of the most accurate predictors available for an individual's future behavior (Davis, 1989).

TAM2 incorporates additional theoretical constructs spanning social influence processes (subjective norm, voluntariness and image) and cognitive instrumental processes (job relevance, output quality, result demonstrability and perceived ease of use). In terms of social influence processes, TAM2 indicates that three interrelated social forces: subjective norm, voluntariness and image will impinge an individual's opportunity to adopt or reject a new system. TAM2 also theorizes that subjective norm will positively influence image because an important members of a person's social group at work believe that he or she should perform a behavior (e.g., using a system), then performing it will tend to elevate his or her standing within the group (Blau 1964, Kiesler 1969, Pfeffer 1982). Individual often respond to social normative influences to establish or maintain a favorable image within a reference group (Kelman 1958). An individual may perceive that using a system will lead to improvements in his or her job 
performance (definition of perceived usefulness) indirectly due to image enhancement, over and above any performance benefits directly attributable to system use. However, when individuals know more about the system’s strengths and weaknesses through direct experience, the normative influence subsides. According to Agarwal and Prasad (1997), who found that "mandating the use of a system can increase initial system utilization," enabling users to “overcome the hurdle of first-time use”, but such normative pressure seems to erode over time (Ram and Jung, 1991). Job relevance is defines as an individual's perception regarding the degree that the target system is applicable to his or her job. TAM2 regards job relevance as a cognitive judgment that exerts a direct effect on perceived usefulness. When a task, system is capable of performing and match their job goals, people will consider how well the system perform those task, which always refers as perceptions of output quality. Output quality used to explain significant unique variance in, perceived usefulness over and above job relevance. Since an effective system may fail to garner user acceptance if people have difficulty attributing gains in their job performance especially to their use of the system. Thus, TAM2 theorizes that result demonstrability defined by Moore Benbasat (1991, p.203) as the “tangibility of the results of using the innovation” will directly influence perceived usefulness. Empirically, Argawal and Prasad (1997) found a significant correlation between usage intention and result demonstrability. There is extensive empirical evidence accumulated over a decade that perceived ease of use us significantly linked to intention, both directly and indirectly through impact on perceived usefulness (Davis et al. 1989, Venkatesh 1999). Figure 2.2 represented the TAM2 model. 


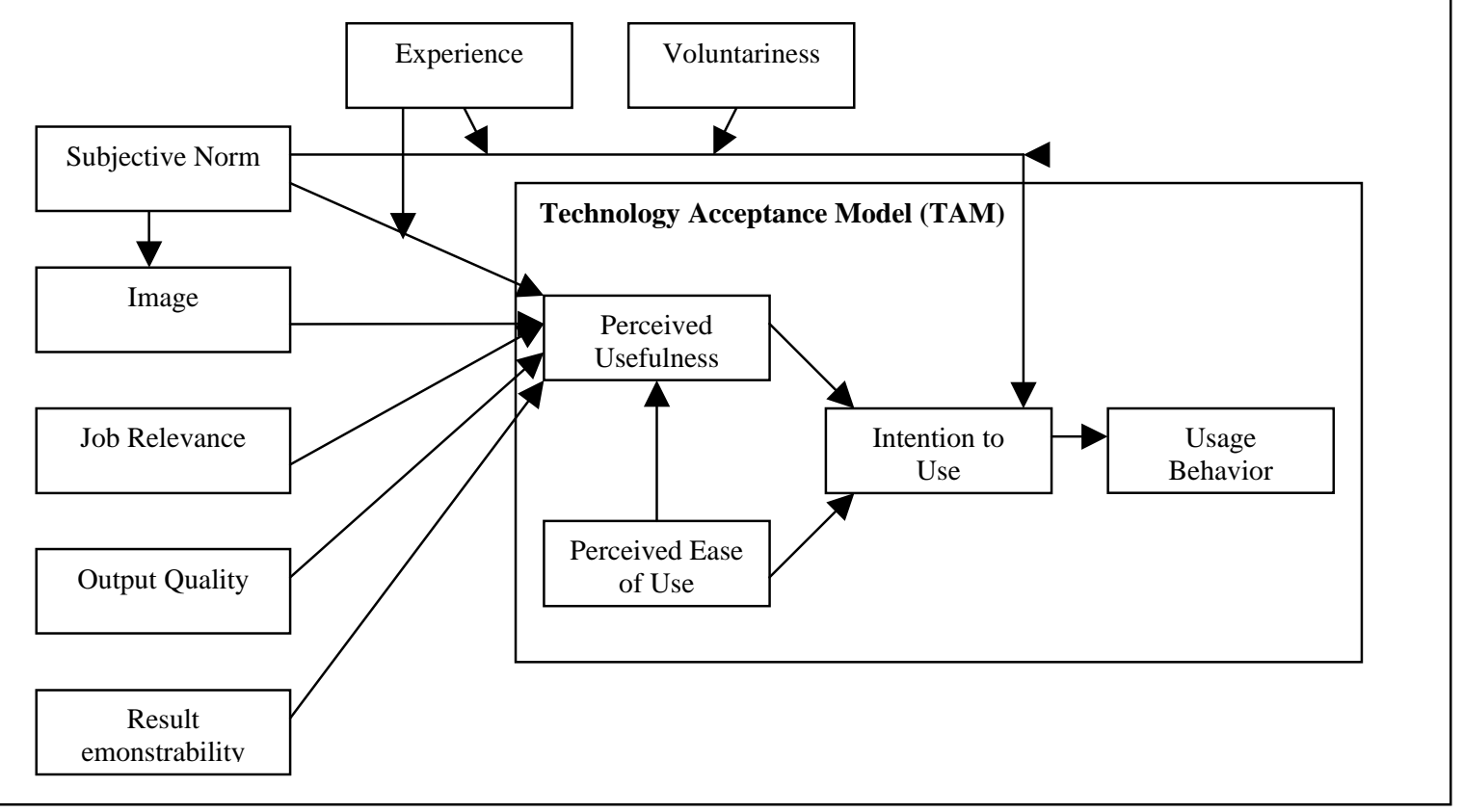

Figure 2.2 Proposed TAM2 - Extension of the Technology Acceptance Model Source: Davis et al., 1989; Venkatesh 1999

\subsubsection{Motivational Model (MM)}

In accordance with Deci (1975), who defined intrinsic motivation as conduct, which deals with the environment, tends to motivate a person's need to feeling competent and self-determining. This intrinsic motivation will decrease if the person is not attaining enjoyment from the activities. Nevertheless, extrinsic motivation activities linked extrinsic rewards, which consequently correlated to satisfaction of primary drives of achieving goal set. For example of positive rewards, it can be money or praise or social approval or positive feedback for fitting into their social reference group.

\subsubsection{Theory of Planned Behaviour (TPB)}

The TPB was proposed as an extension of TRA because of the limitation of TRA in dealing with behaviors over which people have incomplete volitional control (Ajzen, 1991). The components of behavioral attitudes and subjective norms are the same in TPB as in the TRA. 
The difference is TPB has included with additional third determinant of intention, which is called the degree of Perceived Behavioral Control. The inclusion of behavioral control in TPB has added to the explanatory power of TPB (Mathieson 1991, Taylor and Todd 1995). Perceived Behavioral Control (PBC) refers to the perceived ease of difficulty of performing the behavior and it is assumed to reflect internal and external constraints on behavior. TPB suggests that since citizens do not have full control over their online government transactions, perceived behavioral control should become a critical component of e-government adoption. Perceived behavioral control encompasses two components namely "self efficacy" and “facilitating conditions”. Self-efficacy is an individual's self-confidence in his or her ability to perform a behavior (Bandura, 1982); while facilitating conditions representing the resources needed to engage in a behavior (Triandis, 1971). Applied to e-government context, behavioral control should facilitate information acquisition as the citizens have the opportunity and resources to manage such behavioral activities. Similarly, in terms of providing information, a sense of control over how personal information will be managed and used will be likely to affect the behavior. Under TPB model, the intention behavior is predicted by three factors: attitude towards the behavior (A), subjective norms (SN) and perceived behavioral control (PBC). General rule revealed that the more favorable the attitude and subject norm and the greater control, the stronger should be the person's intention to perform the behaviour in question (Ajzen, 1991).

\subsubsection{Combined TAM-TPB (C-TAM-TPB)}

Another complex approach, Taylor and Todd (1995), combined TAM-TPB model the predictors from TAM and TPB model, such as, attitude toward behaviour (adapted from TRA/TPB), subjective norm (adapted from TRA/TPB), perceived behavioral control (adapted from TPB), and perceived usefulness (adapted from TAM) in their studies of assessing IT 